Int Arch Allergy Immunol 1992;99:157-164

\title{
Contents, Vol. 99, No. 2-4, 1992
}

The Carl Prausnitz Memorial Lecture

Ricci, M. T Cells, Cytokines, IgE and Allergic Inflammation 165

The Paul Kallós Memorial Lecture

Kishimoto, T. Interleukin-6 and Its Receptor; From Cloning to Clinic

1. Biochemistry and Molecular Biology of Cellular Activation

Weller, P.F. Intercellular Interactions in the Recruitment and Functions of Human Eosinophils 178

Massey, W.A.; Lichtenstein, L.M. Role of Basophils in Human Allergic Disease 184

Castells, M.; Katz, H.R.; Austen, K.F. $\quad$ Molecular and Cellular Biology of Rodent Mast

Cells 189

Baggiolini, M. Neutrophil Activation and the Role of Interleukin-8 and Related Cytokines 196

Lane, S.J.; Soh, C; Hallsworth, M.P.; Sousa, A.; Litchfield, T.; Poston, R.N.; Arm, J.P.; Lee,

T.H. Monocytes and Macrophages in Asthma 200

Bieber, T.; Ring, J. In vivo Modulation of the High-Affinity Receptor for IgE (FceRI) on Human Epidermal Langerhans Cells 204

Dvorak, A.M.; Schleimer, R.P.; Dvorak, H.F.; Lichtenstein, L.M.; Weller, P.F. Human Lung Mast Cell and Alveolar Macrophage Cytoplasmic Lipid Bodies Contain Arachidonic Acid and

Prostaglandin Endoperoxide Synthase (Cyclooxygenase), the Substrate and Enzyme Necessary for Prostaglandin Production 208

Triggiani, M.; Oriente, A.; de Crescenzo, G.; Marone, G. Sources of Arachidonic Acid in Human Lung Macrophages 218

Warner, J.A.; Peachell, P.T.; Lavens, S.E. Role of Tyrosine Kinases in IgE-Mediated Signal Transduction in Human Lung Mast Cells and Basophils 222

Kroegel, C; Warner, J.A.; Giembycz, M.A.; Dual Transmembrane Signalling Mechanisms in Eosinophils: Evidence for Two 226

Matthys, H.; Lichtenstein, L.M.; Barnes, P.J.Functionally Distinct Receptors for Platelet-

Activating Factor

159

II. Perspectives in Regulation and Function of Immune Cells

Moretta, L.; Ciccone, E.; Biassoni, R.; Poggi, A.; Mingari, M.C.; Moretta, A.

Recent A

Galli, S.J.; Tsai, M.; Wershil, B.K.

Regulatic

Levi-Schaffer, F.; Segal, V.; Nagler, A.

Romagnani, S.; Del Prete, G.; Maggi, E.; Parronchi, P.; De Carli, M.; Macchia, D.; Manetti, R.;

Mast Cel

Sampognaro, S.; Piccinni, M.-P.; Giudizi, M.G.; Biagiotti, R.; Almerigogna, F.

Human T

Askenase, P. W.; Ptak, W. Role of Gamma/Delta T Cells as Positive Regulators of

Alpha/Beta TCR+ Effector 246

T Cells in Allergic Contact Sensitivity 
and Allergy

de Week, A.L. $\quad$ Perspectives in Allergy Diagnosis

Adkinson, Jr., N.F.; Hamilton, R.G.; Creticos, P.S.; Lichtenstein, L.M.; Norman, P.S.

Aalberse, R.C. Clinically Significant Cross-Reactivities among Allergens

Mohapatra, S.S.; Sehon, A.H. Therapeutic Potential of Recombinant Allergens

Valenta, R.; Duchêne, M.; Vrtala, S.; Valent, P.; Sillaber, C; Ferreira, F.; Tejk1, M.; Hirschwehr,

R.; Ebner, C; Kraft, D.; Scheiner, O

Adorini, L.

Immunotherapy of Autoimmune Disease

IV. Frontiers in Immunopharmacology

Marone, G.; de Paulis, A.; Casolaro, V.; Ciccarelli, A.; Spadaro, G.; Cirillo, R.

Alexander, A.G.; Corrigan, C.J.; Barnes, N.C.; Kay, A.B.

Schleimer, R.P.; Kaiser, J.; Tomioka, K; Ebisawa, M.; Bochner, B.S.

Scudeletti, M.; Lanza, L.; Contini, P.; Puppo, F.; Indiveri, F.

Beasley, R.; Pearce, N.; Crane, J.; Burgess, C.

Vacca, A.; Dammacco, F. Deflazacort versus Prednisone in the Treatment of Essential Mixed 306

Cryoglobulinemia: A Between-Patient Controlled Clinical Study

160

Contents

V. Basophils, Mast Cells and Eosinophils

Kaplan, A.P.; Kuna, P.; Reddigari, S.; Rucinski, D.; Baeza, M.; Oppenheim, J.J.; Schall, T.J.

Langdon, J.; MacDonald, S.M. IgE-Dependent Histamine-Releasing Factor: A Unique

Cytokine 316

Bischoff, S.C.; Dahinden, C.A. Effect of the c-kit Ligand on Mediator Release by Human Lung Mast Cells 319

Columbo, M.; Horowitz, E.M.; Botana, L.M.; MacGlashan, Jr., D.W.; Bochner, B.S.; Gillis, S.;

Zsebo, K.M.; Galli, S.J.; Lichtenstein, L.M.

de Paulis, A.; Ciccarelli, A.; Cirillo, R.;

de Crescenzo, G.; Columbo, M.; Marone, G.

Denburg, J.; Dolovich, J.; Kanai, N.; Finotto, S.; Ohno, I.; Marshall, J.; Jordana, M.

Chen, X.-J.; Enerbäck, L. IgE Content and IgE Receptor Expression of Mast Cells in

Normal and Nematode-Infected Rats

Welker, P.; Grabbe, J.; Hakimi, J.; Walls, A.F.; Ostmeier, H.; Czarnetzki, B.M.

Stellato, C; Casolaro, V.; Renda, A.; Genovese, A.; Marone, G.

Okayama, Y.; Church, M.K. IL-3 Primes and Evokes Histamine Release from Human

Basophils but not Mast Cells 343

Macpherson, J.L.; Lopez, A.; Krilis, S.A.

Lapa e Silva, J.R.; Pretolani, M.; Bachelet, CM.; Baker, D.; Scheper, R.; Vargaftig, B.B.

Bonini, S.; Lomassini, M.; Bonini, S.; Capron, M. Balsano, F.

Koshino, L.; Ishii, A.; Ito, K. Bronchial Constriction and Remarkable Infiltration of

Eosinophils in Normal Guinea Pigs by Nasal Drops of Anti-Guinea Pig IgE: A Model for

Asthma

VI. Regulation of IgE Synthesis

Effect of

Modulati

Microen

333

Fibroblas

Anti-Infl:

Co-Cultu

Booster-

; The Eo 
Kenemy, M.; Noble, A.; Diaz-Sanchez, D.; Staynov, D.;Lee, T.

Ricin-Se

Regulatic

Wyss-Coray, T.; Pichler, W.J. Nonclassical Antigen-Presenting Cells Stimulate the Proliferation of ThO but not Thl/Th2 Clones and Modulate the Cytokine Pattern of T-Helper Clones 370

Ito, M.; Matsuzaki, G; Uno, S.; Katakai, Y.; Suko, M.; Endo, S.; Okudaira, H.

Bujanowski-Weber, J.; Fischer, A.; König, W.

Seiberler, S.; Scheiner, O.; Kraft, D.; Valenta, R. Homology of Two cDNAs Coding for Birch Pollen Allergens with Calmodulin: 380

Protein-Bound $\mathrm{Ca} 2+$ Affects the IgE-Binding Capacity

VII. Mechanisms of Inflammation

Graf, K; Niehus, J.; Baumgarten, C.R.; Gräfe, M. Fleck, E.; Kunkel, G.

Role of Endothelial Cells in Inflammatory Processes

382

Brom, J.; König, W.

Signal Transduction and Priming of Human Neutrophils

387

Hitzfeld, B.; Friedrichs, K.H.; Behrendt, H.

In vitro Interaction between Human Basophils and Polymorphonuclear Granulocytes: Effect of Airborne Particulate Matter

390

Mannaioni, P.F.; Di Bello, M.G.; Raspanti, S.; Gambassi, F.; Mugnai, L.; Masini, E. Platelet Histamine: Characterization of the Proaggregatory Effect of Histamine in Human Platelets

394

Brom, C; Brom, J.; König, W.

GTPases and Low Molecular Weight G Proteins during Cell-Cell Interaction between Neutrophils and Platelets

397

Wörner, I.; Hänsch, G.M.; Prior, B.; Rother, K.

Leukocyte Mobilization from Bone Marrow: Effect of the RGD-Containing Peptides 400 of C3 and Fibronectin

Masini, E.; Gambassi, F.; Lupini, M.; Pistelli, A.; Mannaioni, P.F.

Correlation between Nitric Oxide Synthesis and Histamine Release in Mast Cells from

Spontaneously Hypertensive Rats: Influence of Aging

404

Coleman, J.W.; Holliday, M.R.; Buckley, M.G.

Regulation of the Secretory Function of Mouse Peritoneal Mast Cells by IL-3, IL-4 408 and IFN- $\gamma$
Regulatic

Analysis 
Fukuse, S.; Terajima, C; Koontz, A.; Kelley, M.; Webb, D.R.; Devens, B.H. Interleukin-2 Stimulates the Development of Anergy via the Activation of Nonspecific Suppressor T Cells

411

Koseki, H.; Makino, Y.; Adachi, Y.; Taniguchi, M. V-Alpha-14 T-Cell Antigen Receptor Repertoire and Its Function

416

Mathison, R.; Bissonnette, E.; Carter, L.; Davison, J.S.; Befus, D.

The Cervical Sympathetic Trunk-Submandibular Gland Axis Modulates Neutrophil 419 and Mast Cell Functions

VIM. Pathophysiology, Prevention and Treatment of Allergic Disorders

Busse, W.W.; Calhoun, W.J.; Dick, E.C.

Effect of an Experimental Rhinovirus 16 Infection on Airway Mediator Response to Antigen 2

Behrendt, H.; Becker, W.M.; Friedrichs, K.H.; Darsow, U.; Tomingas, R.

Interaction between Aeroallergens and Airborne Particulate Matter

425

Glovsky, M.M.; Farrow, N.; Ross, B.; Ward, P.A.; Morganroth, M.

Hypoxic and Complement-Induced Lung Injury in the Isolated Perfused Rat Lung as Determined by Phosphorous-31 Nuclear Magnetic Resonance

129

Haen, E.; Bleise, U.; Przybilla, B.

Impairment of the B-Adrenergic System of Peripheral Blood Leukocytes in Atopic Patients with Seasonal Allergic Rhinoconjunctivitis

435

Blanca, M.; Moreno, F.; Mayorga, C; Perez, E.; Fernandez, J.; Terrados, S.; Vega, J.M.; Torres, M J.; Juarez, C; Garcia, J.

Immunochemical Analysis of the Specificites of IgE Antibodies Directed to Benzylpenicilloyl 139

Mayorga, C; Blanca, M.; Moscoso, J.; Obispo, J.: del Prado, J.; Sanchez, F.; Juarez, C. Studies of the Epitopes of Amoxicillin by Monoclonal Antibodies 443

Hermann, K; Ring, J.

Changes in Angiotensin Peptides in Plasma and Urine in Patients with Anaphylaxis 446

Rak, S.; Werner, S.; De Vos, C. 
Influence of the Priming Effect with Alder Pollen on Nonspecific Bronchial Hyperreactivity of Asthmatics Specifically Allergic to Birch Pollen

449

Helbling, A.; Lopez, M.; Lehrer, S.B.

Fish Allergy: Is It a Real Problem with Surimi-Based Products

i2

Iikura, Y.; Matsuda, S.; Matsumoto, K.; Hashimoto, K; Akasawa, A.; Obata, T.; Saito, H.;

Matsunaga, T.; Koya, N.

Bronchial Response Study of Asthmatic Patients Using an Atmosphere-Changing

Chamber

1. Reduced Ambient Pressure and Asthmatic's Lung Function

ii

162

Contents

Tsubaki, T.; Iikura, Y.; Saito, H.; Akasawa, A.; Changes in Histamine/Tryptase Levels in Skin Chambers: Application for Clinical 459

Tabana, T.; Matsuda, S.; Koshibu, T.; Iwasaki, A.; Evaluation of Atopic Dermatitis Obata, T.; Sugihara, Y.

Matsuzaki, G.; Shu, U.; Ando, T.; Suko, M.; Ito, K.; Okudaira, H.

Chavarria, J.F.; Carswell, F. House Dust Mite Exposure and Emergency Hospital

Admission of Asthmatic Children

Bergmann, K.-C. A New Allergy Documentation and Information Center in

Germany: The First Museum of Allergology

Borel, Y.; Fritsché, R. Administration of a Tolerogen to Prevent Allergy

Oehling, A.; Sanz, M.L.; Garcia, B.E.

Kips, J.C.; Tavernier, J.H.; Peleman, R.A.; Joos, G.F.; Pauwels, R.A.

Fischer, A.; Bujanowski-Weber, J.; König, W.

Meingassner, J.G.; Stütz, A. Anti-Inflammatory Effects of Macrophilin-Interacting Drugs in Animal Models of Irritant and Allergic Contact Dermatitis

A $\tau$ iti-Der

Nakagawa, T.; Yamashita, N.; Mizushima, Y.; Ishii, A.; Ito, K.; Nambu, F.; Motoishi, M.; Yui, Y.; Shida, T.; Miyamoto, T. Inhibition of Allergic Bronchoconstriction in Guinea Pigs and in Asthmatics by the Leukotriene Antagonist ONO-1078

Dorsch, W.; Wagner, H.; Neszmelyi, A.; Stuppner, H.

Dorsch, W.; Hess, V. Noninvasive Analysis of Lung Function in Small Animals: Compressed Air, 496

Thoracic Gas Volume, Airway Resistance, Maximal Flow Rates, Tidal Volume, Breathing

Frequency, I/E Ratio

Author Index 499

Subject Index

502 